\title{
Reused second life batteries for aggregated demand response services
}

\author{
Lluc Canals Casals a, Mattia Barbero ${ }^{\text {a, * }}$, Cristina Corchero ${ }^{\text {a, b }}$ \\ a Catalonia Institute for Energy Research (IREC), Jardins de les Dones de Negre 1, 2, 08930, Sant Adrià de Besòs, Barcelona, Spain \\ ${ }^{\mathrm{b}}$ Universitat Politecnica de Catalunya (UPC), Carrer Jordi Girona, 1-3, 08034, Barcelona, Spain
}

\section{A R T I C L E I N F O}

\section{Article history:}

Received 31 May 2018

Received in revised form 11 October 2018

Accepted 1 December 2018

Available online 3 December 2018

\section{Keywords:}

Circular economy

Second life

Demand response

Energy flexibility

Batteries

Demand aggregator

\begin{abstract}
A B S T R A C T:
The electric vehicle is presented as an environmental friendly alternative to common vehicles and as the future of transportation. However, car manufacturers consider that electric vehicle batteries are not useful for traction purposes when they reach a state of health of $80 \%$. Thus, as a matter of fact, these batteries are sold knowing that they have a premature obsolescence, as they still have $80 \%$ of useful capacity that could be used elsewhere.

This study analyzes economically and in terms of ageing performance the possibility to provide a second life to these batteries in buildings. The study presents several scenarios depending on the battery use, considering independent buildings or getting closer to the concept of smart grid with demand response services where buildings could participate in secondary electricity markets by means of an energy aggregator. Moreover, the study analyzes the existing European markets that allow aggregated demand response services.

Results show that, effectively, the reuse of batteries for residential purposes might not be the best economical option even though their lifespan is enlarged four years more. Nonetheless, if they are able to participate in secondary electricity markets in addition to their normal use in buildings, the business becomes juicy enough having a relatively low impact on ageing.

The promotion of electric vehicle battery reuse is necessary, as there is a large amount of batteries with a huge useful potential in stationary applications coming in the nearby future from the electric vehicles that have been sold during the last five years. If possible, car manufacturers should consider eco-design in order to facilitate this battery repurposing and lifespan enlargement.
\end{abstract}

(C) 2018 Elsevier Ltd. All rights reserved.

\section{Introduction}

Electric Vehicles (EV) are slowly but steadily entering into the automotive market proclaiming a cleaner future in the transportation sector. Although EV production entails higher environmental impacts than the internal combustion engine vehicle's (ICEV) manufacture (Hawkins et al., 2013), EV do not have tailpipe emissions (Nordelöf et al., 2014). Moreover, as their environmental impact during the use phase strongly depend on the power source that produces the electricity to charge their batteries (Sullivan and Gaines, 2012), the usage of renewable self-produced energy for charging de battery would reduce the overall environmental impact. In fact, it is during the use phase when the overall environmental impact of EV improves, although in countries with high penetration of pollutant technologies in the electricity mix EVs and

\footnotetext{
* Corresponding author.

E-mail address: mbarbero@irec.cat (M. Barbero).
}

ICEVs might end up having a similar global warming potential at the end of their life-cycle.

It occurs that the end-of-life (EoL) of EVs is not fixed by a failure but by car manufacturer's marketing decisions (Canals Casals, Amante García and Cremades, 2017). EV batteries performance and capacity reduces with its use in a similar way to batteries in laptops or cellphones. However, battery lifetime in small devices plays a minor role in comparison to what it is expected for EVs (Vetter et al., 2005). While laptops and cellphones can be charged almost everywhere and even when they are in use, an EV needs to reach its destination in order to charge the battery again. As the EV range reduces accordingly to the battery capacity (Andrew, 2009), it is widely accepted that EV batteries are not useful for traction purposes when they lose between $20 \%$ and $30 \%$ of its initial capacity (Waldmann et al., 2014), (Martinez-Laserna et al., 2016). Moreover, the loss of performance is widely known to be related to the battery internal resistance increase, which has a direct effect on efficiency, heating and maximum power (Ecker et al., 2012), (Dubarry et al., 


\section{List of abbreviations}

$\begin{array}{ll}\text { DER } & \text { Distributed Energy Resources } \\ \text { DOD } & \text { Depth-Of-Discharge } \\ \text { DR } & \text { Demand Response } \\ \text { DSO } & \text { Distribution System Operator } \\ \text { EMS } & \text { Energy Management System } \\ \text { EoL } & \text { End-of-Life } \\ \text { ESS } & \text { Energy Storage System } \\ \text { EV } & \text { Electrical Vehicles } \\ \text { FCR } & \text { Frequency Containment Reserves } \\ \text { FRR } & \text { Frequency Restoration Reserves } \\ \text { HVAC } & \text { Heating, Ventilation and Air Conditioning } \\ \text { ICEV } & \text { Internal Combustion Engine Vehicle } \\ \text { PV } & \text { Photovoltaic } \\ \text { RR } & \text { Replacement Reserves } \\ \text { SOC } & \text { State Of Charge } \\ \text { SOH } & \text { State Of Health } \\ \text { TSO } & \text { Transmission System Operator }\end{array}$

2011). In fact, the power loss might be specially critical at low state of charge (SOC) (Dubarry et al., 2007), when the voltage drop caused by the internal resistance might suddenly cross the lower voltage limit causing an unexpected stop. Nonetheless, the effects of the internal resistance increase at $80 \%$ of State-Of-health $(\mathrm{SOH})$ are relatively low in comparison to capacity fade. In consequence, it is fair enough to assume that the EoL of EV batteries is defined not by user's needs but by the interest of car manufacturer in having a client that does not notice a shortening in the performance of his EV.

Knowing that the EoL is fixed for commercial reasons rather than by real constraints or impediments, researchers took two directions when considering what to do next: some focused their work in determining a more accurate $\mathrm{SOH}$ limit of the battery while others considered alternative battery uses after the EV is dismantled and prior to recycling, which is the research line considered for in this study.

Regarding the SOH limit, Jaguemont et al. state that temperature can be a serious problem for cold countries due to its effect on ageing and instant performance (Jaguemont et al., 2016). Moreover, some voices indicate that there is a relation between ambient temperature and the distance driven by EVs (Yuksel and Michalek, 2015), mostly based on cabin temperature control, but also affected by the driving habits (Neubauer and Wood, 2014). Additionally, an experimental study on EV efficiency confirmed these analysis claiming that there is an increase in the EV consumption due to cold temperatures that is dramatically aggravated when temperature cabin control is active, having around a $65 \%-75 \%$ consumption increment depending on the driving cycle (De Gennaro et al., 2014). These temperature changes occur along all seasons of the year and even during the day in many places worldwide. In addition to temperature, auxiliary loads (Liu et al., 2017), driving behavior (Vatanparvar et al., 2018) and type (urban vs highway) trips (Yuan et al., 2017), can also affect the EV energy consumption. Therefore, the possibility that the EV owners notice the battery degradation is definitively blurred by all the possible driving conditions and variations, thus, owners would hardly identify when the battery reached this $80 \%$ SOH. Finally, Saxena et al. indicate that many EV owners would continue using his EV well beyond the $80 \%$ SOH limit according to their usual trips, as most of them do not need the whole battery capacity to reach their destination and because some cars owners may not want to acquire a new battery so early (Saxena et al., 2015).

In addition to all previous analysis of the determination of the EoL, there is the issue regarding the accuracy of the existing methods to monitor $\mathrm{SOH}$. In fact, inaccurate $\mathrm{SOH}$ estimation methods may delay or accelerate the moment when batteries are retired. The more precise and reliable techniques to evaluate $\mathrm{SOH}$ are those that need to test the battery on their own, such as the electrochemical impedance spectroscopy, the pulse and the capacity tests. However, these tests are expensive and time consuming, forcing researchers to study on-board estimation techniques. Nowadays, methods such as internal resistance monitoring (Remmlinger et al., 2011) are being questioned due to the difficulties to obtain precise measures. Thus, internal resistance estimation models using several methods such as extended Kalman filter or recursive least squares among others, although they need too much computational efforts (Mathew et al., 2018). Then, there are other on-board alternatives such as voltage recovery (Lluc Canals Casals et al., 2016a,b), or the incremental of capacity vs voltage curves (Mathew et al., 2018) that may properly work. Finally, new EV models tend to have higher capacity (and longer range as a consequence), confirming that maybe this $80 \% \mathrm{SOH}$ limit of the battery EoL should be adjusted.

The second research branch analyzes the possibility to reuse these EV batteries (Chiang et al., 2017) assuming that EVs will be dismantled after they reach the $80-70 \% \mathrm{SOH}$ threshold. This idea appears as a link between two sectors, the transportation sector that should face the management of EV batteries as a waste product knowing that their cost is almost half of the EV cost, and the electricity sector that is eager to use affordable energy storage systems (ESS) for different stationary applications. In fact, although the price of lithium-ion batteries, which are the ones preferred by EV manufacturers, is in continuous descent, they are still too expensive to be massively deployed in stationary applications (Robson and Bonomi, 2018). Thus, second life EV batteries can cover this market niche and definitively launch ESS for electricity grid purposes thanks to their lower expected prices (Neubauer et al., 2012), (Foster et al., 2014).

Grid services can be divided in three categories: power quality, grid support and bulk power management services. ESS fit in one or another category depending on the power they should offer in a period of time. Except for bulk management services that are generally covered by pumped hydro and compressed air ESS, lithium ion batteries are suitable for almost all other stationary services (Dunn et al., 2011), (Reid G.Julve, 2016).

Many of the services included in power quality and grid support categories require high power and energy installations, going from $100 \mathrm{~kW}$ to an order of MW, as many of the demonstrators already installed show (Dunn et al., 2011). This represents a large amount of EV batteries in a single installation. As EV batteries are not designed for second life applications (Bauer et al., 2017), there are several impediments that difficult their stacking for these type of applications. For one side, there is the need to modify messages from each battery in order to identify which one is sending them as they all send the same messages. Then, it is also necessary to solve the electric isolation architecture caused by vehicle legislations (Canals Casals and Amane García, 2016). Moreover, EV batteries are best sized for residential and commercial use (Andrew, 2009), (Bräuer et al., 2016). Unfortunately, ESS for residential use does not seems the best market to start with from an economic perspective, being grid support services the ones showing higher revenues (Neubauer and Pesaran, 2011).

However, this latter fact is maybe no more an impediment for massive reused battery deployment as the figure of the aggregator using distributed energy resources (DER) for demand response (DR) expands. The aggregator is understood as a stakeholder that acts 
into the energy markets taking advantage of different flexibility sources. One of the business model analyzed for this new stakeholder takes advantage of the intelligence in smart buildings to modify the energy consumption of the building according to the electricity grid needs. Considering that the impact of one single building on the electricity grid is almost negligible, aggregators add the energy flexibility of many buildings to significantly correct deviations in the electricity grid (Del-Rosario-Calaf et al., 2017), (Luo et al., 2015). As development goes on and cities convert to smart cities, the amount of buildings counting with DER and controllable loads increase. Most smart buildings are able to adapt the thermal energy demand (Behboodi et al., 2018) and to manage renewable power sources they might have (Braun and Strauss, 2008). However, batteries (Olivella-Rosell et al., 2018), EVs (Akhavan-Rezai et al., 2017) and household intelligent devices such fridges or washing machines among others may also contribute to the calculation of flexibility (Ayón et al., 2017), (Diekerhof et al., 2017). To activate this flexibility of buildings, the use of economic incentives is a common practice (Kotsis et al., 2015). It is thanks to the economic incentives of these secondary electricity markets that batteries in buildings may substantially increase their revenue expectations.

Moreover, adding flexibility to the grid from the consumer's side will be fundamental in Europe to reach the objectives of emissions reduction and increase of renewable's share. DR has been identified as a key actor for reaching these objectives (Shariatzadeh et al., 2015). The aggregator will allow consumers to trade their flexibility saving money and helping the system stability. This same author also indicates that batteries are probably the most reliable flexibility source for demand side response, as it is relatively simple to know exactly the power and the energy available in each moment, in contrast with all the others DR sources that affect directly consumers, such as Heating, Ventilation and Air Conditioning (HVAC) or water heating systems. Furthermore, using batteries for changing the consumption pattern does not affect the comfort of the client, as their usage will not have a direct impact on consumers. That can be a great advantage for batteries to enter in secondary markets, assuming a low marginal cost for aggregators. Two main pillars for aggregators' selection of activated flexibility will be a low comfort affectation of its clients and a great reliability of the source.

This study takes advantage of the information retrieved from a second life EV battery installed in a public library near Barcelona within the framework of the REFER project (https://refer.upc.edu/ ca) to estimate its lifetime enlargement thanks to this second life opportunity. A battery electric equivalent circuit model will be used to estimate the battery ageing according to its use in the library comparing three different working scenarios, which are: selfconsumption, self-consumption and DR, self-consumption and DR with frequency regulation. The scenarios are defined in the material and methods' section.

As seen, even though research and technology is ready to adopt second life batteries and that car manufacturers have launched many demonstration projects in this direction, there is still not an EV model whose battery is designed using eco-design methodologies neither considering the circular economy opportunities that these batteries have in the electricity market.

Therefore, this study aims to highlight how the EV market, which is growing and has huge expectations, begins with a planned or premature obsolescence even knowing that there are many economic and environmental interesting alternatives. Moreover, this study analyzes how the EV battery lifespan is enlarged by reusing them on stationary applications in buildings providing DR services to stabilize the electricity grid. With this, this study analyzes the current status of DR markets in Europe and presents a business model that contributes to enlarge the product lifetime perspective via multiple product cycles.

\section{Material and methods}

Technical requirements for participating in balancing markets are very strict and depend on the type of secondary market in which aggregators aim to participate. This section describes the different types of secondary markets present in Europe and their main characteristics.

Following ENTSOE's (European Network of Transmission System Operators for Electricity) terminology, secondary markets can be divided in three groups, depending on the function and on technical requirements needed for entering in the market (ENTSO-E, 2012).

- Frequency Containment Reserves (FCR): are the first reserves activated in order to reestablish grid frequency at an acceptable level. The objective is not to reestablish the frequency at the desired level but just to respond very fast to disturbances or incidents. The activation is made automatically and in order of seconds, apart to be activated continuously.

- Frequency Restoration Reserves (FRR): are activated to restore the system frequency at the desired level after an event occurs. Its range of activity goes from several seconds up to $15 \mathrm{~min}$ after the incident.

- Replacement Reserves (RR): are activated when FRR/FCR are exhausted, giving them time to be reestablished. The activation is manual and the Transmission System Operator (TSO) or the Distribution System Operator (DSO) can decide to activate RR also in case of forecast of imbalances in the grid. The duration of the service and the time of notice depend on the country but generally go from $15 \mathrm{~min}$ to hours.

Batteries are considered ideal for FCR and FRR services as they have a fast response and good relation between power and capacity to work continuously during $15 \mathrm{~min}$. In this way, they can participate in FCR services injecting energy to the grid when the frequency is lowing or charging whenever there is an increase in the frequency. Moreover, thinking in second life EV batteries, this type of service can be very suitable to enlarge their life, as they have a great instantaneously power that is not common in stationary installations and batteries do prefer variations in their working profile and low Depth-of-Discharge (DoD). Similarly, for FRR services, most of the power of the battery may be intended for grid balancing in secondary response. Combining both services can suppose additional incomes without affecting the normal battery's ageing or even improving it.

Despite European Directives incentives European Countries to open their markets to demand aggregator agents and DR (SEDC, 2017), only few countries (shown in Fig. 1) have already opened the market to aggregators, having each one of them their specific technical requirements. Nonetheless, there are some common aspects, such as a minimum bid size, the notification time, the maximum number of activations, the product resolution, the symmetry of the offer and the duration of the activation, that are considered in all countries although having different limitations.

Table 1 shows the range of values for the technical requirement mentioned above for the principal European markets that allow the participation of an aggregator for DR (Nordic countries, UK, France, Germany, and Belgium). It can be appreciated that the minimum bid size is generally lower for FCR services than for other markets. Notice the particularities regarding the number of activations for each service as FCR are continuously activated, FRR are commonly activated several times a week (although it ranges from 2 times a 


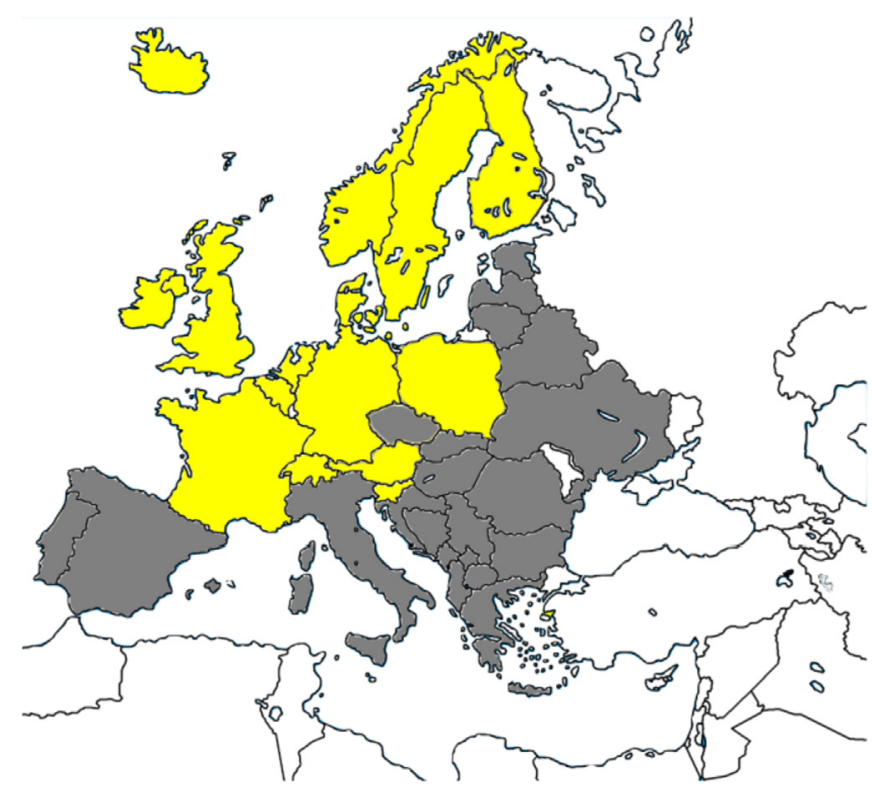

Fig. 1. European countries in which demand aggregator's market is opened (in yellow) (For interpretation of the references to colour in this figure legend, the reader is referred to the web version of this article.)

year to unlimited calls depending on the country) and RR are activated more sporadically.

A part from technical requirements, this study also takes into account the economic conditions for these services. These services have economic retributions regarding concepts such as availability and/or utilization. Payments for availability represent the incomes that the source receive just for being available in case of necessity from the TSO. Thus, these payments are in $€ / M W$ per h and usually correspond to the most important part of the gains for this type of services. The other part of revenues come from utilization, meaning the energy provided to the grid due to a change in the consumption/production pattern. Table 2 presents the ranges of these retributions in major European markets.

Economically speaking, penalizations might play an important role in the final accountability of these services, nonetheless, as the aggregator counts on different power sources, it is assumed that in the case of a failure in one of them, the aggregator will be able to switch rapidly to other sources to provide the desired response. Moreover, it is expected that the aggregator would know the reality of each source at all times, therefore, it would not ask for a service if, for instance, the building is not able to give it. For this reason, penalizations are not considered in this study.

\subsection{Study framework}

This study is based in the installation of a 2nd life EV battery in a public library in Montgat, near Barcelona, within the framework of the REFER project. The original battery comes from a Renault
Table 2

Summary of availability and utilization payments in major secondary markets in Europe.

\begin{tabular}{lll}
\hline Type of service & $\begin{array}{l}\text { Availability payments } \\
{[€ / \mathrm{MW} / \mathrm{h}]}\end{array}$ & $\begin{array}{l}\text { Utilization payments } \\
{[€ / \mathrm{MWh}]}\end{array}$ \\
\hline FCR & $3,87-46$ & $0-1,5$ \\
FRR & $3,07-18,26$ & $0-$ regulating power price \\
RR & $2,27-3,57$ & $0-167,53$ \\
\hline
\end{tabular}

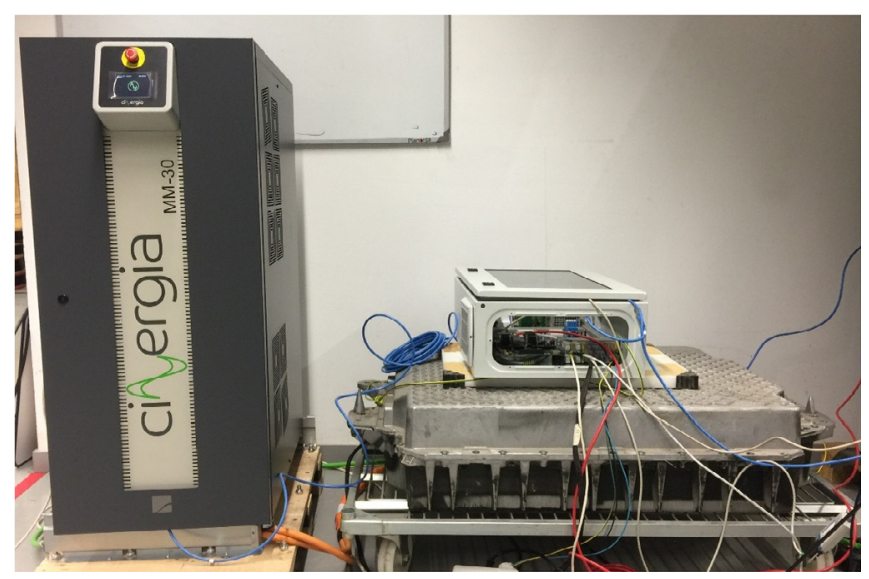

Fig. 2. Second life EV Battery (right) and regulator from Cinergia (left) in the testing facilities.

Kangoo and had an initial capacity of $23 \mathrm{kWh}$. Due to its normal use in the $\mathrm{EV}$, the actual capacity is around an $80 \%$ of the original value, that is, $18,4 \mathrm{kWh}$. This battery is built in two series of 92 NickelManganese-Cobalt (NMC) cells in parallel. Each cell has a capacity of 32,4 Ah. In its actual configuration in the library, the maximum power that the battery can provide is limited to $10 \mathrm{~kW}$ by the inverter or regulator. This regulator has been specially developed for this project by Cinergia(See Fig. 2).

The battery is expected to initially work following two objectives: to store the excess of energy produced by the 96 photovoltaic (PV) panels on the rooftop of the library, which have a maximum generation power of $19,8 \mathrm{kWp}$, and to take advantage of the price differences in the electricity tariff, consuming energy at night, when fares are low, and delivering it whenever prices increase according to the hourly discrimination tariff contracted by the library (Table 3). Costs of energy and power are divided in three time periods. These tariffs do not include taxes. The power contracted by the library is $86,7 \mathrm{~kW}$.

The aim of this study is to evaluate the economic results regarding the electricity behavior of the building in different scenarios:

- Scenario 1, without battery: that is, the library as it was before the installation of the 2nd life battery. Notice that the energy excess from PV is delivered for free to the grid.

Table 1

Summary of technical requirements of major markets in Europe.

\begin{tabular}{|c|c|c|c|c|c|c|}
\hline Service & Minimum bid size [MW] & Notification time & Maximum activations & Product resolution & Symmetry & Duration \\
\hline FCR & $0,1-3$ & $2 \mathrm{~s}-3 \mathrm{~min}$ & Continuously $^{\mathrm{a}}$ & $1 \mathrm{~h}$ & NO-YES & Very fast \\
\hline FRR & $1-10$ & $5 \min -15 \min$ & 2 times/year -Unlimited & $\begin{array}{l}15 \mathrm{~min} \\
1 \mathrm{~h}\end{array}$ & NO & $\begin{array}{l}15 \mathrm{~min} \\
1 \mathrm{~h}\end{array}$ \\
\hline $\mathrm{RR}$ & $1-10$ & $10 \min -4 h$ & $<10$ h/year - Several calls/day & $1 \mathrm{~h}$ & NO & $2 \mathrm{~h}$ \\
\hline
\end{tabular}

\footnotetext{
a Except for Finland and Denmark that runs it only for several time per hour and the $0.1 \%$ of time respectively.
} 
Table 3

Electricity hourly discriminated tariff of the library.

\begin{tabular}{|c|c|c|c|c|}
\hline & From $29 / 10$ to $26 / 03$ & From $27 / 03$ to $28 / 10$ & Term of power supply [€/kW per day] & Term of energy consumption $[€ / \mathrm{kWh}]$ \\
\hline Period 1 & $18-22 \mathrm{~h}$ & $11-15 \mathrm{~h}$ & 0,111185 & 0,097181 \\
\hline Period 2 & $8-18+22-24 h$ & $8-11+15-24 h$ & 0,066952 & 0,083213 \\
\hline Period 3 & $0-8 \mathrm{~h}$ & $0-8 \mathrm{~h}$ & 0,044634 & 0,055568 \\
\hline
\end{tabular}

- Scenario 2, with battery: this is the initial configuration of the battery in the library. The energy absorbed and delivered from the battery is simulated based on the control program that manages the building's energy consumption. This Energy Management System (EMS) stores the energy whenever there is an excess from the solar panels and at midnight, when electricity prices are lower and the library energy consumption decreases. The energy stored during the night is then used during period 1 and 2, when electricity is more expensive.

- Scenario 3, battery with aggregated FRR services: this scenario incorporates the activity of an aggregator that will call the building to offer secondary frequency response sporadically. It considers the baseline consumption of the Scenario 2 adding the participation of the building in FRR markets using the battery capacity and power (limited to $10 \mathrm{~kW}$ ). The calls from the TSO are simulated using a summary of the various markets. The TSO does an average of 40 calls a month, resulting in 1,3 calls per day, with product resolution of $1 \mathrm{~h}$ and a duration of delivery that can vary between $15 \mathrm{~min}$ and $1 \mathrm{~h}$. Each day, the number of activations comes from a Normal distribution with an average of 1,3 calls per day and a standard deviation equal to 0,7 . Similarly, the duration of the activation varies randomly between $15 \mathrm{~min}$ and $1 \mathrm{~h}$. Finally, the direction of the upward or downward regulation is also triggered randomly. Notice that if the battery is discharged before $8 \mathrm{~h}$ due to a TSO's call, it will be immediately recharged after the end of the service to take advantage from the cheapest energy price.

- Scenario 4, battery with aggregated FRR + FCR services: in this scenario, the building will participate in the primary frequency response markets in addition to the secondary frequency response markets from Scenario 3. The technical conditions of the FCR market are: continuous activations, symmetry of the offer and a product resolution of $1 \mathrm{~h}$. Nonetheless, as the available power of the battery is limited to $10 \mathrm{~kW}$, the participation in both markets is split in two, reserving $8 \mathrm{~kW}$ for FRR (working in a similar way as in the third scenario) and $2 \mathrm{~kW}$ for FCR services.

Additionally, there are two more partial scenarios regarding the FRR + FCR aggregated services that will consider some restrictions to the sporadic frequency response market. In Scenario $4 \mathrm{~b}$ the library will only participate in FRR services discharging the battery from 0 to $8 \mathrm{~h}$ and in Scenario 4c it will not offer FRR services during peak hours when energy has a higher cost. These two scenarios are analyzed because the injection of energy to the grid is payed at lower price than the library energy tariff. Period 1 and period 2 in Table 3 are those in which the energy is clearly more expensive than the marginal price of energy in ancillary services; in consequence, it may occur that payments for delivering secondary market services would be not enough to compensate the faster ageing of the battery caused by the necessary additional energy exchanges.

Fig. 3 presents the available flexibility of the building in Scenarios 3, 4, 4b and $4 \mathrm{c}$ during the $24 \mathrm{~h}$ of the day, showing the particularities of Scenarios $4 \mathrm{~b}$ and $4 \mathrm{c}$ and the lower power availability for FRR services in Scenario 4 compared to Scenario 3. Flexibility should be understood as the power that the building

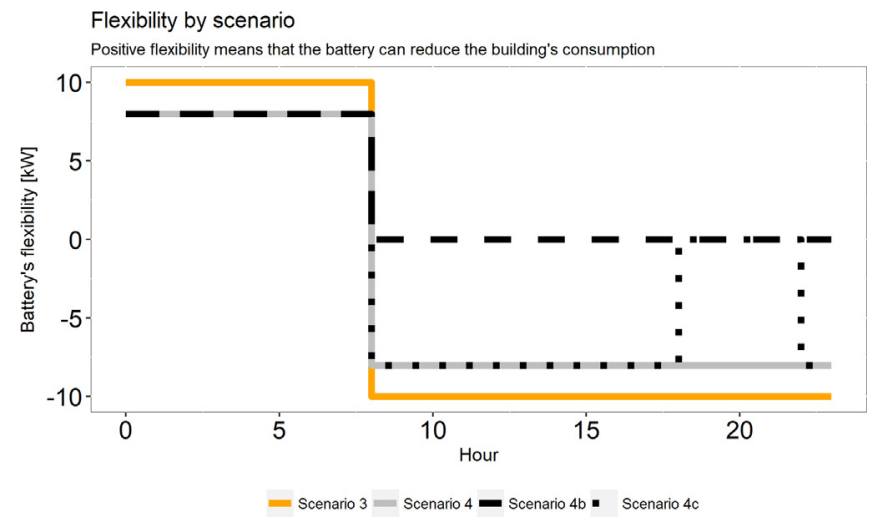

Fig. 3. Battery flexibility for each scenario per hour.

provides for FRR services.

Notice that in cases of coincidence of several factors such as hours of low consumption, high generation and high SOC of the battery (that may occur in sometimes during week-ends or holydays), the building will not participate in the FRR market, thus, it will not receiving any income for availability from the aggregator.

\subsection{Battery ageing}

To correctly proceed with this economic evaluation it is important to estimate the 2nd life battery cost and ageing in all scenarios, as the battery use normally accelerates ageing. Therefore, this study tries to determine if the higher energy demand of the battery caused by the participation in these secondary markets (and ageing as a consequence) worth its cost.

The ageing of the battery is estimated using a 2nd life battery electric-equivalent circuit model represented by a resistance and four resistance/capacitor pairs in series which runs on Matlab and Simulink ${ }^{\circledR}$. This model is described in full details in (Canals Casals et al., 2017a,b) and it has been used in similar second life applications by these same authors (Canals Casals and Amante García, 2017). The particularity of this model is that it regards the ageing of the battery at cell level needing only the electricity current going through it and the working temperature, which are the main two factors affecting battery ageing (Barré et al., 2013). Thus, the parameters of the cells where adapted to the ones from the battery of RENAULT, which have the same NMC technology, in order to obtain results that are more reliable. The model dynamically computes the Depth-Of-Discharge (DoD) and instant SOC, which are the other two relevant factors with direct impact on battery ageing (Vetter et al., 2005). Then, it evaluates the ageing occurred on each timestep of the simulation, obtaining the evolution of SOH along time and use. The specific configuration of this model considers both cycling ageing (due to the battery use) and calendar ageing (that occurs when stored or during stand-by periods).

The data acquisition of the current going through the battery was obtained after processing the data retrieved from the monitoring system that the library has installed. This system allowed us to retrieve the power generated by the solar panels, the energy 
consumed by the building, the amount of energy purchased from the electricity grid and the excess of solar energy injected to the grid whenever there was an overproduction every fifteen minutes. Fig. 4 shows the energy consumed by the building (orange) and how much of it came from the electricity grid (grey) during two weeks (30/10-12/11).

Notice that when the electricity grid curve is below the building's consumption curve, it means that the building consumes energy from the solar panels until it reaches the 0 value, when the library is fully powered by renewable energy power sources and there is an excess of power generation delivered to the grid.

The study counts on data stored during 352 days (from 1st October 2017 to 17th September 2018), since the monitoring equipment was installed. This information is enough for the economic calculation of the first scenario, as there is no battery in it. Knowing the open circuit voltage and SOC of the battery at all times, the current going through it is easily obtained by diving the power by the voltage of the battery according to the SOC.

The activity of the FCR service is taken from a signal that the Spanish TSO (Red Eléctrica de Espanya, REE) sent during $31 \mathrm{~h}$ to a company that participates in FRR + FCR markets. The FCR signal changes every 10 seconds and it fits to the maximum $2 \mathrm{~kW}$ available in our case. This $31 \mathrm{~h}$ period is repeated uninterruptedly for the whole duration of the simulation. Notice that, in Scenarios 4, 4b and 4c, although $2 \mathrm{~kW}$ of power are reserved for FCR services, the full battery capacity is available for the building and for FRR services.

Fig. 5 represents the current going through the battery that was used for the simulation of the battery ageing in these three scenarios for the hours 48 to 72 (third day of simulation) as an example. Notice that Scenarios 2 and 3 are almost similar except for a small deviation at hour 65 caused by the call of the TSO/DSO. Then, current from Scenario 4 is much more variable but peaks are of lower intensity.

Scenarios $4 \mathrm{~b}$ and $4 \mathrm{c}$ follow the same description than Scenario 4 but reducing the possible calls from the TSO to provide FRR services. Thus, in these two additional sub-scenarios there is less energy demand than in Scenario 4.

\subsection{Economic analysis}

The economic evaluation takes into account the electricity tariffs of the library from Table 3 but also the values from secondary markets. Two different market frameworks have been considered for the economic analysis.

As Spain, where the library is located, has no regulation on DR, neither for energy aggregation, the first framework (European framework hereinafter) takes into account the characteristics of the various markets described in Table 2 to assume a possible Spanish

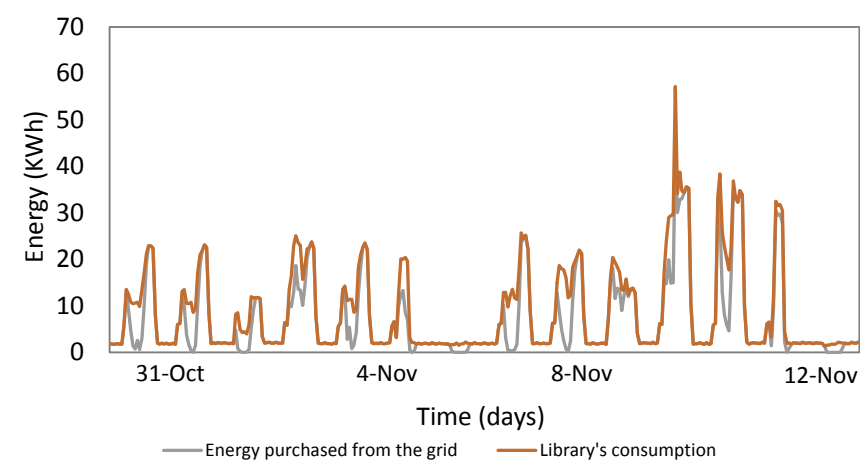

Fig. 4. Library's consumption and energy purchased from the grid during 2 weeks (30 October-12 November).

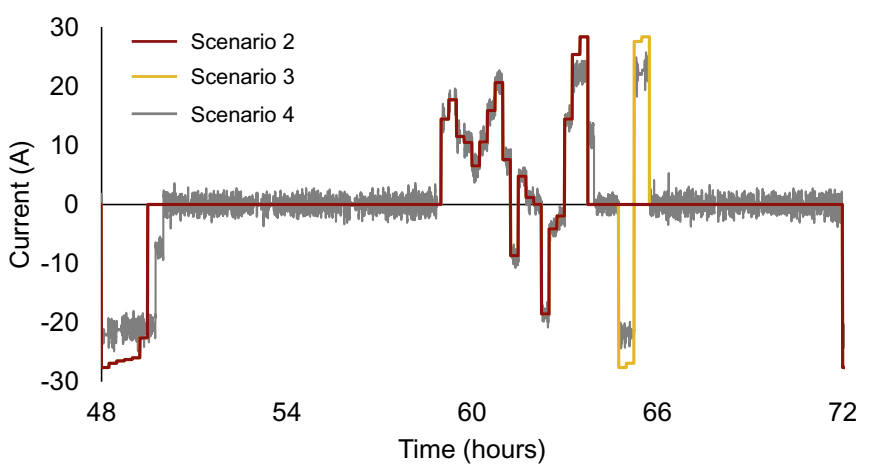

Fig. 5. Current going through the battery in Scenarios 2, 3 and 4.

aggregator. In this case, payments are both for availability and utilization, supposing availability payments of $4 € / \mathrm{MW} /$ hour and utilization payments equal to the payments for energy utilization in the secondary market in Spain for downward or upward regulation during the period considered (October 2017 to September 2018). This decision is in line with all the markets analyzed. Regarding FCR services, availability payments will be of $5 € / M W$ every hour, without utilization payments.

The second framework (Spanish actual framework hereafter) considers the Spanish FRR market although secondary markets are not yet open in the region for demand aggregators. In Spain, primary regulation is mandatory and it is not economically rewarded. All energy generators should reserve at least 1,5\% of their power for primary regulation (BOE, 2006). As not all the sources in building's demand response are able to offer primary frequency control, batteries become a key element in the aggregator business. In Spain, availability payments for frequency control in FRR are higher than those considered in the previous framework and vary depending on the hour and on the day (Red Eléctrica de España, 2018). Notice that the Spanish actual framework force symmetrical market bids in contrast to the market considered in the previous case. In this framework, the aggregator has to be able to manage its offers to the TSO, keeping into account that upward and downward offers have to coincide. For this reason, availability payments of the Spanish market have been divided by two for counting the contribution of the battery that will offer flexibility just in one direction.

In both cases consumers will receive the same treatment as producers. When the TSO asks generators to reduce their production, they are paid depending on the energy price of the secondary market and, additionally, they earn money from the unproduced energy that they had already sold in the day-ahead market. So, following the same criteria, when the battery has to charge due to a call from the TSO, the consumer will receive a discount equal to the price in the day-ahead market in that hour. In this way, the TSO does not spend more money for activating consumers instead of producers and consumers are not excessively penalized for consuming energy when the energy is more expensive.

\section{Results and discussion}

This section will begin with the analysis of the results regarding the battery ageing to further go on with the economic study.

FRR market simulation for Scenario 3 resulted in a total number of upwards and downwards calls by the aggregator of 253 and 223 times respectively.

Fig. 6 shows how the frequency adjustments from the FCR services that where so clearly visible (grey) in the current profile in Fig. 5 are almost unappreciable on the battery voltage evolution (i.e. 


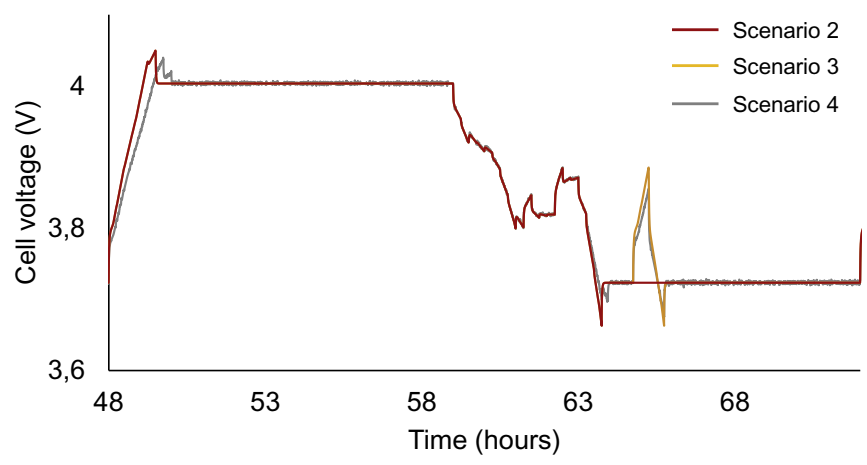

Fig. 6. Example of the resulting voltage of a cell in the battery during one day.

on SOC). This is caused basically due to the fact that the direction (or sign) of current varies so rapidly that it has almost no effect on the accumulated energy throughput and, thus, on SOC. In fact, in terms of energy, the maximum accumulated deviation from the base case (Scenario 3, in orange) is around a $0,3 \%$. On the contrary, the differences between Scenario 2 (red), which participates in no secondary markets, and Scenario 3 (orange) are visible by peaks appearance or displacement in several moments.

Although the continuous and fast current ripples of FCR services represent, in the end, more than $15 \%$ of the total amount of energy exchanged by the battery its impact on ageing should be low as they correspond to a really small DoD (Warnecke, 2015) and batteries can improve their performance with this kind of behavior (Lacey et al., 2013).

As a result of the input current (Fig. 5) at a constant temperature of $20^{\circ} \mathrm{C}$ (the temperature in the room where the battery is installed in the library is controlled), the ageing battery model shows appreciable differences in the $\mathrm{SOH}$ evolution along time (Fig. 7).

During this time lapse, the battery lost around a $5 \%$ of its capacity, being the Scenario 2 and $4 \mathrm{~b}$ the ones with lesser ageing and Scenario 3 the one with higher ageing, as shown in Table 4. This represents that the Rest of Useful Life (RUL) for these second life EV batteries in stationary applications would increase for 3 to 3.5 more years if the EoL is defined at $\mathrm{SOH} 64 \%$ (that is an $80 \%$ of the beginning of the second life, which is already an $80 \%$ of the capacity of a new battery). Going beyond this limit is not foreseen as there is a risk to fall into the ageing knee, an acceleration of the ageing rate (Martinez-Laserna et al., 2016), and due to the fact that the internal resistance of the battery also increases substantially (Ecker et al., 2012).

In fact, the participation in FRR services (Scenario 3) represents an increase on ageing of around a $13,5 \%$ in comparison to Scenario

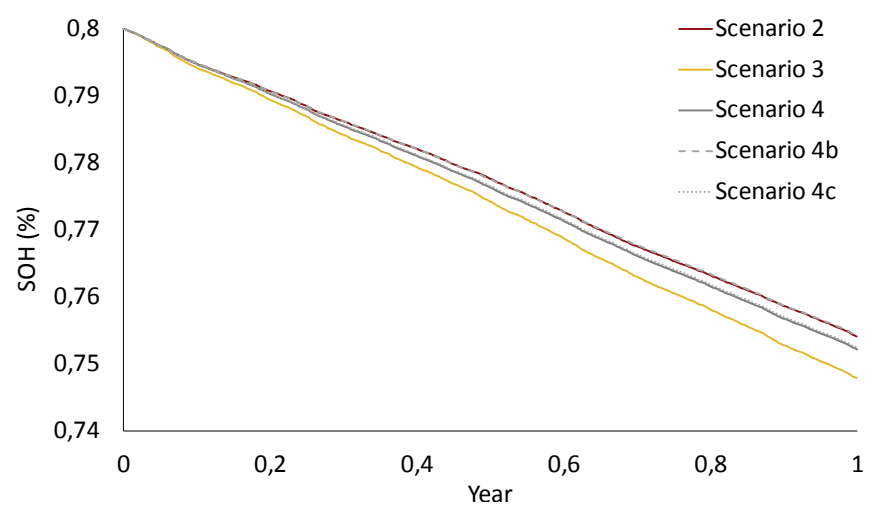

Fig. 7. Battery ageing (or SOH evolution) through time.
2. Similarly, Scenario 4, participating in FCR and FRR services, also ages faster than Scenario 2 (4,2\% more) but lesser than Scenario 3. Scenarios $4 \mathrm{~b}$ and $4 \mathrm{c}$, due to its fewer calls by the aggregator, age less than Scenario 4.

However, an analysis of ageing considering time as the main factor might be misleading. In fact, as shown in Table 4, Scenario 4 does 1,08 equivalent full cycles per day (understood as the total amount of energy divided by the capacity of the battery or cell), while Scenario 2 does only 0,91 cycles, which means that, at the end of the simulation, the battery does 393 and 333 cycles respectively.

In consequence, the higher ageing rate per cycle (or per $\mathrm{kWh}$ ) is found in Scenario 2, which is also the one with longer lifespan, while the best performance is found in Scenarios 4, 4b and 4c, having $89 \%$ of the ageing per cycle of Scenario 2. The "Ageing per cycle" line in Table 4 represents the variation of ageing per full equivalent cycle in relation to the ageing obtained in Scenario 2, reason why Scenario 2 has a 100\% ageing per cycle.

This study considers that a second life EV battery such as the one presented in this study should cost between $700 €$ and $2.500 €$ according to lower bounds of $38,3 € / \mathrm{kWh}$ (Neubauer et al., 2015) and higher bounds of $140 € / \mathrm{kWh}$ (Canals Casals, Amante García and González Benítez, 2016). Notice that this costs are considerably lower than the cost of new batteries that ranges from 300 to $500 € / \mathrm{kWh}$. Additionally, the economic analysis includes the costs from power electronics, such as the converter that charge and discharge the battery, which is assumed to be $5000 €$ according to market.

Scenario 1 is the starting point for the economic evaluation of second life batteries in the building, that is, the use of electricity in the library without battery. In this case, energy costs considering tariffs described in Table 3 rise up to $8.607 €$ regarding the electricity consumption and $8.706 €$ corresponds to the power contracted, giving a total of $17.314 €$ during the 352 days considered in the study.

Scenario 2 includes the use of the battery in the building without any contract with the aggregator. The amount of savings during the whole period thanks to the use of the battery are $345,3 €$ including taxes, of which $175,0 €$ come from consuming energy during valley hours instead of peak hours and about $170,3 €$ correspond to the increase self-consumption.

In Scenario 3, the battery will participate 214 times of the 476 (253 up and 223 down) possible calls during the period considered in the FRR market. There are 262 missed calls from the TSO that correspond to moments when the library was not available for the aggregator (903 h during the period considered) or the call went in the opposite direction of the battery's available flexibility. Effectively, the library suffers a cost increase of electricity consumed of $20,9 €$ in respect to Scenario 2 including taxes due to a non-optimal building management caused by the participation in secondary markets. The difference in billing among having aggregator or not is very small due to the fact that energy requested from aggregator's activation will be recovered just afterwards when the electricity price is still the same. However, in some cases, there is a cost increment whenever there is a shift of consumption between billing periods. Total incomes of the aggregator for the second life battery services were $109,7 €$ for energy utilization and $301,7 €$ for availability payments considering incomes of $4 € / \mathrm{MW}$ each hour for FRR services. Payments for availability represent more than $73 \%$ of the incomes for the aggregator.

In Scenario 4 the battery will participate 217 times during the period considered in the FRR market. In this case, as the flexibility offered to the market is $8 \mathrm{~kW}$ instead of $10 \mathrm{~kW}$, there are $851,5 \mathrm{~h}$ in which the battery can't change its pattern instead of the $903 \mathrm{~h}$ of the previous case. The library's bill will increase $18,9 €$ including 
Table 4

$\mathrm{SOH}$ evolution and ageing resulting from the Battery model.

\begin{tabular}{|c|c|c|c|c|c|}
\hline & Scenario 2 & Scenario 3 & Scenario 4 & Scenario 4b & Scenario 4c \\
\hline Initial SOH & 0,8000 & 0,8000 & 0,8000 & 0,8000 & 0,8000 \\
\hline SOH after 1 year & 0,7541 & 0,7479 & 0,7522 & 0,7543 & 0,7525 \\
\hline Difference & 0,0459 & 0,0521 & 0,0478 & 0,0457 & 0,0475 \\
\hline Ageing increase & $0.0 \%$ & $13,5 \%$ & $4,2 \%$ & $-0,3 \%$ & $3,7 \%$ \\
\hline Ageing per year & $4,6 \%$ & $5,2 \%$ & $4,8 \%$ & $4,6 \%$ & $4,8 \%$ \\
\hline Equivalent full cycles & 333 & 380 & 393 & 371 & 388 \\
\hline Cycles per day & 0,91 & 1,04 & 1,08 & 1,02 & 1,06 \\
\hline Ageing per cycle & $100,0 \%$ & $99,5 \%$ & $88,3 \%$ & $89,5 \%$ & $89,0 \%$ \\
\hline RUL (Years) & 3,5 & 3,1 & 3,3 & 3,5 & 3,4 \\
\hline Final eq. full cycles & 1.162 & 1.168 & 1.316 & 1.298 & 1.306 \\
\hline
\end{tabular}

taxes. Differences in the bill among Scenario 3 and 4 are due to a reduction in the self-consumptions, as the power available by the battery is reduced. Considering the European framework, the aggregator would gain a total of $416,5 €$. In the Spanish actual framework, aggregator's profits thanks to the battery would correspond to $88,9 €$ for energy utilization and $429,7 €$ for availability in FRR markets as the Spanish market has no revenue for FCR availability. The total income is $518,6 €$.

In Scenario $4 \mathrm{~b}$, when the battery offers flexibility just for discharge from $0 \mathrm{~h}$ to $8 \mathrm{~h}$, it participates in the FRR market just 87 times during the time considered. The library electricity costs increase $16,9 €$ compared to Scenario 2 and payments to aggregator from the TSO in the European framework rise up to $198,7 €$. Considering the Spanish market framework, payments to aggregator would be 221,6 $€$.

Finally, in Scenario 4c, the building will participate in FRR balancing services 196 times during the period considered. The battery does not participate in the market from $11 \mathrm{~h}$ to $15 \mathrm{~h}$ during summer and from $18 \mathrm{~h}$ to $22 \mathrm{~h}$ during winter and during $49 \mathrm{~h}$ in which it is not able to offer flexibility for changing its pattern. Thus, the electricity cost is $18,5 €$ more expensive than in Scenario 2, but thanks to the battery, the aggregator will receive a total amount of $368,4 €$ considering the European market framework and 455,4€ considering the Spanish actual framework.

Table 5 represents a summary of the economic analysis for each scenario during the days considered. For simplicity, for the calculation of the library's profits during the period considered it is supposed that the $80 \%$ of the aggregator's gains are given to its clients. Therefore, the total library's incomes are calculated as the savings with respect to the electricity bill in Scenario 1 plus the $80 \%$ of the aggregator's revenues.

Once the effect of the participation in different markets on the second life battery ageing and the economic savings and gains that a battery produces in different scenarios is analyzed, it is worth to combine the technical and the economic analysis for understanding the best way to use a second life battery in stationary applications.

To calculate the range of the amortization costs of the overall system during the monitored year, the study considers the amortization costs of converter and battery. For the converter, an amortization period of 20 years is considered (grey bar in Fig. 8), while for the battery it is considered that the battery costs are applied until reaching the EoL, defined at $\mathrm{SOH} 64 \%$. To translate this cost to the duration of the simulation the calculations where done considering the corresponding $\mathrm{SOH}$ variation. As an example, in Scenario 2 , the battery ages a $4,6 \%$ of $\mathrm{SOH}$, corresponding to an amortization cost in the range of 230 and $920 €$. Finally, the profit from the library is obtained by subtracting the amortization costs of the system (uncertainty bar) to the savings of the library (orange bar) and incomes from the aggregator (yellow bar) for each scenario.

Results are visible in Fig. 8 showing that, effectively, batteries for self-consumption use only (Scenario 2) do not offer any economic incentive. In fact, batteries suppose an inevitable cost. The situation

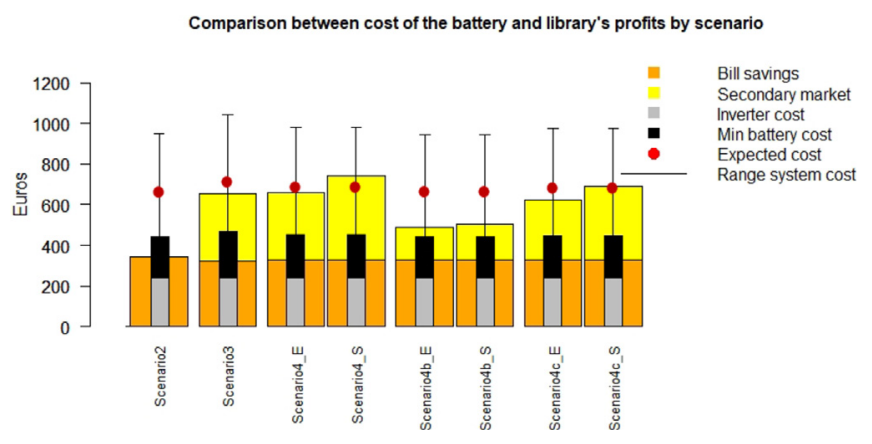

Fig. 8. Costs and profits by scenario.

Table 5

Economic analysis by scenario.

\begin{tabular}{|c|c|c|c|c|c|c|}
\hline & $\begin{array}{l}\text { Total bill } \\
{[€]}\end{array}$ & $\begin{array}{l}\text { Energy utilization FRR } \\
{[€]}\end{array}$ & $\begin{array}{l}\text { FRR availability } \\
{[€]}\end{array}$ & $\begin{array}{l}\text { FCR availability } \\
{[€]}\end{array}$ & $\begin{array}{l}\text { Total aggregator profits } \\
{[€]}\end{array}$ & $\begin{array}{l}\text { Total library's profits } \\
{[€]}\end{array}$ \\
\hline Scenario 1 & 17314,1 & 0 & 0 & 0 & 0 & 0 \\
\hline Scenario 2 & 16968,7 & 0 & 0 & 0 & 0 & 345,3 \\
\hline Scenario 3 & 16989,6 & 109,7 & 301,7 & 0 & 411,4 & 653,7 \\
\hline Scenario 4 European Framework & 16987,6 & 88,9 & 243,1 & 84,5 & 416,5 & 659,7 \\
\hline Scenario 4 Spanish actual framework & & & 429,7 & 0 & 518,6 & 741,38 \\
\hline Scenario 4b European framework & 16985,6 & 24,1 & 90,1 & 84,5 & 198,7 & 487,5 \\
\hline $\begin{array}{l}\text { Scenario 4b Spanish actual } \\
\text { framework }\end{array}$ & & & 197,5 & 0 & 221,6 & 505,8 \\
\hline Scenario 4c European framework & 16987,2 & 77,0 & 206,9 & 84,5 & 368,4 & 621,6 \\
\hline $\begin{array}{l}\text { Scenario 4c Spanish actual } \\
\text { framework }\end{array}$ & & & 378,4 & 0 & 455,4 & 691,2 \\
\hline
\end{tabular}


changes considerably in the scenarios that count on ancillary services, where profits may occur depending on the final cost of the 2nd life battery and the final market framework in Spain. It seems that Scenario 4 considering the actual Spanish framework is the best option. In fact, nowadays, the price of 2 nd life batteries from 4Renergy is close to $2.300 €$, but considering that other car manufacturers will enter into this market niche and that remanufacturing processes will be automatized, 2 nd life battery costs could be assumed to reduce down to $1.500 €(83 € / \mathrm{kWh})$ (red dot in Fig. 8).

Notice that, apart from Scenario $4 \mathrm{~b}$, in all cases the amortization costs of the system are higher than in Scenario 2, however, these costs are clearly compensated by the additional revenues from the market (basically from availability). In addition, the best option in the two market frameworks is ever to offer flexibility at all the hours of the day, as availability payments is the most important part of the incomes for secondary markets, also in this case higher amortization costs and an higher electricity bill is clearly compensated by the additional revenues.

\section{Conclusions}

The main objective of this work was to demonstrate that there are interesting markets for second life EV batteries, which are built without caring about their future premature obsolescence although EV market is in continuous growing.

This study combines the knowledge on battery ageing depending on the use with a technical and economic analysis of the secondary electricity markets in Europe and the monitoring data of a library in Montgat, Barcelona, Spain.

In the first place, this study shows that battery lifespan increases by a $35 \%$ with the incorporation of second life applications in buildings.

In all the scenarios considered with the presence of the aggregator, incomes plus savings thanks to the incorporation of energy storage systems are higher than the amortization costs of the battery plus inverter considering the optimistic lower bound of 2nd life battery price of $700 €$. However, considering lesser optimistic battery costs, results change considerably and it might be rather difficult to obtain high profitability from these kind of businesses. Nonetheless, capacity payments considered in this study are rather conservative, thus, results might be more interesting in the future Spanish market.

This study showed that the ageing of battery plays a relevant role in the final results, showing that the participation in FCR markets clearly reduces the amortization costs of the battery due to a reduction of ageing per $\mathrm{kWh}$ delivered (ageing/cycle) maintaining the economic incomes.

Moreover, this study shows that the lower selling price of 2nd life EV batteries in comparison to new ones opens a new market niche that would be prohibitive otherwise. Additionally, it clearly states that the integration of the figure of an aggregator is necessary to run demand response services from a customer perspective.

Furthermore, 2nd life batteries could reduce the effective price of EVs and reduce its life cycle impacts.

\section{Acknowledgments}

The authors gratefully acknowledge the project REFER (COMRDI15-1-0036), funded by ACCIÓ and the European Regional Development Fund (FEDER) under the RIS3CAT Energy Community. This research has also been financially supported by the research and innovation programme Horizon 2020 European Union under the grant agreement nr. 731211 SABINA. C. Corchero work is supported by the grant IJCI-2015-26650 (MICINN).
All researchers have been partially supported by the Generalitat de Catalunya (2017 SGR 1219).

\section{References}

Akhavan-Rezai, E., Shaaban, M.F., El-Saadany, E.F., Karray, F., 2017. Managing demand for plug-in electric vehicles in unbalanced LV systems with photovoltaics. IEEE Trans. Ind. Informatics 13, 1057-1067. https://doi.org/10.1109/TII.2017. 2675481.

Andrew, B, 2009. Performance, charging and second use considerations for lithium batteries for plug-in electric vehicles. In: The Electricity Storage Association Meeting, Session on Transportation and Grid. Institute of Transportation Studies.

Ayón, X., Gruber, J.K., Hayes, B.P., Usaola, J., Prodanović, M., 15 July 2017. An optimal day-ahead load scheduling approach based on the flexibility of aggregate demands. Appl. Energy 198, 1-11. https://doi.org/10.1016/j.apenergy.2017.04.038.

Barré, A. Deguilhem, B., Grolleau, S., Gérard, M., Suard, F, Riu, D., 2013. A review on lithium-ion battery ageing mechanisms and estimations for automotive applications. J. Power Sources 241, 680-689. https://doi.org/10.1016/j.jpowsour. 2013.05.040.

Bauer, T., Zwolinski, P., Mandil, G., Monnier, É., 2017. Conception de batteries repurposées: quels paramètres de conception et comment les définir?. In: 15e Colloque National AIP-Prim_eca. La Plagne, France https://doi.org/hal01518693.

Behboodi, S., Chassin, D.P., Djilali, N., Crawford, C., 2018. Transactive control of fastacting demand response based on thermostatic loads in real-time retail electricity markets. Appl. Energy 210, 1310-1320. https://doi.org/10.1016/j. apenergy.2017.07.058.

BOE, 2006. I. Disposiciones Generales. Boletín Of. del Estado, pp. 44142-44156. https://doi.org/10.1017/СВ09781107415324.004.

Bräuer, S., Monhof, M., Klör, B., Plenter, F., Siemen, C., Beverungen, D., 2016. Residential energy storage from repurposed electric vehicle batteries - market overview and development of a service-centered business model. In: Proceedings of the IEEE Conference on Business Informatics (CBI 2016), pp. 143-152. https://doi.org/10.1109/CBI.2016.24.

Braun, M., Strauss, P., 2008. A review on aggregation approaches of controllable distributed energy units in electrical power systems. Int. J. Distr. Energy Resour. 4, 297-319.

Canals Casals, L., Amane García, B., 2016. Communications concerns for reused electric vehicle batteries in smart grids. IEEE Commun. Mag. 54, 120-125. https://doi.org/10.1109/MCOM.2016.7565258.

Canals Casals, L., Amante García, B., 2017. Second-life batteries on a gas turbine power plant to provide area regulation services. Batteries 3,10. https://doi.org/ 10.3390/batteries3010010.

Canals Casals, L., Amante García, B., Cremades, L.V., 2017a. Electric vehicle battery Reuse : preparing for a second life. J. Ind. Eng. Manag. 10, 266-285. https://doi. org/https://doi.org/10.3926/jiem.2009.

Canals Casals, L., Amante García, B., González Benítez, M., 2017b. Aging model for Re-used electric vehicle batteries in second life stationary applications. In: Lecture Notes in Management and Industrial Engineering. Springer International Publishing, pp. 139-151. https://doi.org/10.1007/978-3-319-51859-6_10.

Canals Casals, L., Amante García, B., González Benítez, M., 2016a. A cost analysis of electric vehicle batteries second life businesses. In: Capuz-Rizo, J.L.A.M., Yagüe Blanco, J.L., Salvador, F. (Eds.), Lecture Notes in Management and Industrial Engineering, Project Management and Engineering Research, 2014. Springer International Publishing, pp. 129-141. https://doi.org/10.1007/978-3-31926459-2.

Canals Casals, L., Schiffer Gonzalez, A., Amante, B., Llorca, J., 2016b. PHEV battery ageing study using voltage recovery and internal resistance from On-board data. IEEE Trans. Veh. Technol. 65, 4209-4216. https://doi.org/10.1109/TVT. 2015.2459760.

Chiang, Y.H., Sean, W.Y., Wu, C.H., Huang, C.Y., 2017. Development of a converterless energy management system for reusing automotive lithium-ion battery applied in smart-grid balancing. J. Clean. Prod. 156, 750-756. https://doi.org/10.1016/j. jclepro.2017.04.028.

De Gennaro, M., Paffumi, E., Martini, G., Manfredi, U., Scholz, H., Lacher, H., Kuehnelt, H., Simic, D., 2014. Experimental investigation of the energy efficiency of an electric vehicle in different driving conditions. In: SAE 2014 World Congress \& Exhibition. https://doi.org/10.4271/2014-01-1817.

Del-Rosario-Calaf, G., Rocamora, S., Corchero, C., 2017. Design of an algorithm to deliver demand side flexibility from aggregated resources to distribution system operators. In: IEEE PES Innovative Smart Grid Technologies Conference Europe. https://doi.org/10.1109/ISGTEurope.2016.7856267.

Diekerhof, M., Peterssen, F., Monti, A., 2017. Hierarchical distributed robust optimization for demand response services. IEEE Trans. Smart Grid 3053, 1. https:// doi.org/10.1109/TSG.2017.2701821.

Dubarry, M., Liaw, B.Y., Chen, M.S., Chyan, S.S., Han, K.C., Sie, W.T., Wu, S.H., 2011 Identifying battery aging mechanisms in large format Li ion cells. J. Power Sources 196, 3420-3425. https://doi.org/10.1016/j.jpowsour.2010.07.029.

Dubarry, M., Svoboda, V., Hwu, R., Liaw, B.Y., 2007. Capacity and power fading mechanism identification from a commercial cell evaluation. J. Power Sources 165, 566-572. https://doi.org/10.1016/j.jpowsour.2006.10.046.

Dunn, B., Kamath, H., Tarascon, J.-M., 2011. Electrical energy storage for the grid: a 
battery of choices. Science 334, 928-935. https://doi.org/10.1126/science. 1212741.

Ecker, M., Gerschler, J.B., Vogel, J., Käbitz, S., Hust, F., Dechent, P., Sauer, D.U., 2012. Development of a lifetime prediction model for lithium-ion batteries based on extended accelerated aging test data. J. Power Sources 215, 248-257. https:// doi.org/10.1016/j.jpowsour.2012.05.012.

ENTSO-E, 2012. Operational Reserve Ad Hoc Team Report 1-58.

Foster, M., Isely, P., Standridge, C.R., Hasan, M.M., 2014. Feasibility assessment of remanufacturing, repurposing, and recycling of end of vehicle application lithium-ion batteries. J. Ind. Eng. Manag. 7, 698-715. https://doi.org/10.3926/ jiem.939.

Hawkins, T.R., Singh, B., Majeau-Bettez, G., Strømman, A.H., 2013. Comparative environmental life cycle assessment of conventional and electric vehicles. J. Ind. Ecol. 17, 53-64. https://doi.org/10.1111/j.1530-9290.2012.00532.x.

Jaguemont, J., Boulon, L., Dubé, Y., 2016. A comprehensive review of lithium-ion batteries used in hybrid and electric vehicles at cold temperatures. Appl. Energy 164, 99-114. https://doi.org/10.1016/j.apenergy.2015.11.034.

Kotsis, G., Moschos, I., Corchero, C., Cruz-Zambrano, M., 2015. Demand aggregator flexibility forecast: price incentives sensitivity assessment. In: International Conference on the European Energy Market. EEM, pp. 1-5. https://doi.org/10. 1109/EEM.2015.7216756.

Lacey, G., Jiang, T., Putrus, G., Kotter, R., 2013. The effect of cycling on the state of health of the electric vehicle battery. In: 2013 48th Int. Univ. Power Eng. Conf, 1-7. https://doi.org/10.1109/UPEC.2013.6715031.

Liu, K., Wang, J., Yamamoto, T., Morikawa, T., 2017. Exploring the interactive effects of ambient temperature and vehicle auxiliary loads on electric vehicle energy consumption. Appl. Energy 227, 324-331. https://doi.org/10.1016/j.apenergy. 2017.08.074.

Luo, X., Wang, J., Dooner, M., Clarke, J., 2015. Overview of current development in electrical energy storage technologies and the application potential in power system operation. Appl. Energy 137, 511-536. https://doi.org/10.1016/j. apenergy.2014.09.081.

Martinez-Laserna, E., Sarasketa-Zabala, E., Stroe, D., Swierczynski, M., Warnecke, A., Timmermans, J.M., Goutam, S., Rodriguez, P., 2016. Evaluation of lithium-ion battery second life performance and degradation. In: IEEE Energy Conversion Congress and Expo. Milwakee. https://doi.org/10.1109/ECCE.2016.7855090.

Mathew, M., Janhunen, S., Rashid, M., Long, F., Fowler, M., 2018. Comparative analysis of lithium-ion battery management systems. Energies 11,1-15. https:// doi.org/10.3390/en11061490.

Neubauer, J., Pesaran, A., 2011. The ability of battery second use strategies to impact plug-in electric vehicle prices and serve utility energy storage applications. J. Power Sources 196, 10351-10358. https://doi.org/10.1016/j.jpowsour.2011.06. 053.

Neubauer, J., Pesaran, A., Williams, B., Ferry, M., Eyer, J., 2012. A Techno-economic analysis of PEV battery second use _ repurposed battery selling price and commercial and industrial end_user value. In: SAE World Congress and Exhibition. Detroit. https://doi.org/10.4271/2012-01-0349.

Neubauer, J., Smith, K., Wood, E., Pesaran, A., Neubauer, J., Smith, K., Wood, E., Pesaran, A., 2015. Identifying and Overcoming Critical Barriers to Widespread Second Use of PEV Batteries Identifying and Overcoming Critical Barriers to Widespread Second Use of PEV Batteries 23-62. https://doi.org/NREL/TP-540063332.
Neubauer, J., Wood, E., 2014. Thru-life impacts of driver aggression, climate, cabin thermal management, and battery thermal management on battery electric vehicle utility. J. Power Sources 259, 262-275. https://doi.org/10.1016/j. jpowsour.2014.02.083.

Nordelöf, A., Messagie, M., Tillman, A.-M., Ljunggren Söderman, M., Van Mierlo, J., 2014. Environmental impacts of hybrid, plug-in hybrid, and battery electric vehicles-what can we learn from life cycle assessment? Int. J. Life Cycle Assess 19, 1866-1890. https://doi.org/10.1007/s11367-014-0788-0.

Olivella-Rosell, P., Bullich-Massagué, E., Aragüés-Peñalba, M., Sumper, A., Ottesen, S.Ø., Vidal-Clos, J.A., Villafáfila-Robles, R., 15 January 2018. Optimization problem for meeting distribution system operator requests in local flexibility markets with distributed energy resources. Appl. Energy 210, 881-895. https://doi.org/10.1016/j.apenergy.2017.08.136.

Red Eléctrica de España, 2018. Sistema de informacion del operador del sistema. WWW Document. https://www.esios.ree.es/en (accessed 5.14.18).

Reid, G., Julve, J., 2016. Second Life-batteries as Flexible Storage for Renewables Energies.

Remmlinger, J., Buchholz, M., Meiler, M., Bernreuter, P., Dietmayer, K., 2011. State-ofhealth monitoring of lithium-ion batteries in electric vehicles by on-board internal resistance estimation. J. Power Sources 196, 5357-5363. https://doi.org/ 10.1016/j.jpowsour.2010.08.035.

Robson, P., Bonomi, D., 2018. Growing the battery storage market 2018: exploring four key issues. In: Energy Storage World Forum. Dufresne.

Saxena, S., Le Floch, C., Macdonald, J., Moura, S., 2015. Quantifying EV battery endof-life through analysis of travel needs with vehicle powertrain models. J. Power Sources 282, 265-276. https://doi.org/10.1016/j.jpowsour.2015.01.072.

SEDC, 2017. Explicit Demand Response in Europe Mapping the Markets 20171-223.

Shariatzadeh, F., Mandal, P., Srivastava, A.K., 2015. Demand response for sustainable energy systems: a review, application and implementation strategy. Renew. Sustain. Energy Rev. 45, 343-350. https://doi.org/10.1016/j.rser.2015.01.062.

Sullivan, J.L., Gaines, L., 2012. Status of life cycle inventories for batteries. Energy Convers. Manag. 58, 134-148. https://doi.org/10.1016/j.enconman.2012.01.001.

Vatanparvar, K., Faezi, S., Burago, I., Levorato, M., Faruque, M.A. Al, 2018. Extended range electric vehicle with driving behavior estimation in energy management. IEEE Trans. Smart Grid 14, 1-10. https://doi.org/10.1109/TSG.2018.2815689.

Vetter, J., Nov, P., Wagner, M.R.R., Veit, C., Novák, P., Möller, K.-C., Besenhard, J.O. Winter, M., Wohlfahrt-Mehrens, M., Vogler, C., Hammouche, A., 2005. Ageing mechanisms in lithium-ion batteries. J. Power Sources 147, 269-281. https:// doi.org/10.1016/j.jpowsour.2005.01.006.

Waldmann, T., Wilka, M., Kasper, M., Fleischhammer, M., Wohlfahrt-Mehrens, M., 2014. Temperature dependent ageing mechanisms in Lithium-ion batteries - a Post-Mortem study. J. Power Sources 262, 129-135. https://doi.org/10.1016/j. jpowsour.2014.03.112.

Warnecke, A., 2015. Ageing effects of Lithium-ion batteries. In: 17th Conference on Power Electronics and Applications, pp. 1-20.

Yuan, X., Zhang, C., Hong, G., Huang, X., Li, L., 2017. Method for evaluating the realworld driving energy consumptions of electric vehicles. Energy 141, 1955-1968. https://doi.org/10.1016/j.energy.2017.11.134.

Yuksel, T., Michalek, J.J., 2015. Effects of regional temperature on electric vehicle efficiency, range, and emissions in the United States. Environ. Sci. Technol. 49, 3974-3980. https://doi.org/10.1021/es505621s. 